\title{
Genetic relationship among gill-infecting Myxobolus species (Myxosporea) of cyprinids: molecular evidence of importance of tissue-specificity
}

\author{
Edit Eszterbauer*
}

Veterinary Medical Research Institute, Hungarian Academy of Sciences, PO Box 18, 1581 Budapest, Hungary

\begin{abstract}
The importance of tissue-specificity was studied in Myxobolus spp. infecting the gills of 7 cyprinid species. The 18S rDNA of 10 Myxobolus species was amplified by optimised nested-PCR, resulting in $\sim 1600$ bp PCR products. Phylogenetic trees generated by distance matrix and parsimony analyses revealed 4 main groups. Muscle-infecting species all belonged to the same group, while members of 2 gill-infecting groups were clearly distinguishable on the basis of tissue-specificity, and were also recognisable by differences in spore morphology. On the basis of tissue tropism, phylogenetic relationships among the species examined indicate that genetic separation is a more ancient evolutionary feature than host-specificity.
\end{abstract}

KEY WORDS: Myxobolus · Myxosporeans $\cdot$ Phylogeny $\cdot 18 \mathrm{~S}$ rDNA $\cdot$ Tissue tropism $\cdot$ Cyprinids $\cdot$ Gills

\section{INTRODUCTION}

The genus Myxobolus is one of the richest groups among myxosporeans, containing about 450 valid species (Landsberg \& Lom 1991). These species have been identified principally on the basis of spore morphology, although additional features such as organ- and tissuespecificity of intrapiscine development stages and the identity of the host species have also been used for specific assignments (Molnár 1994, Molnár \& Székely 1999).

As molecular biological methods have become increasingly important in parasitological studies, the taxonomic classification of myxosporeans has been expanded with phylogenetic analyses. Phylogenetic trees produced by $18 \mathrm{~S}$ rDNA sequences of myxosporeans available in the GenBank largely agreed with Shulman's (1966) phylogenetic hypotheses, and have revealed the importance of several phenotypic features in species identification (Kent et al. 2000, 2001). Based on the 18S rDNA sequences of 10 myxosporean species, Andree et al. (1999) found that parasite spe- cies were related mostly by their location in the tissue of the fish host. Examinations of 5 Kudoa species suggested that members of this genus are segregated more by host and geographic origin than by spore morphology (Hervio et al. 1997). On the other hand, Salim \& Desser (2000), using the 18S rDNA sequences of 7 Myxobolus species from cyprinids, found that the parasites were grouped by spore morphology. Studying the genetic relationships among closely related Myxobolus species infecting the skeletal muscle of cyprinids, Molnár et al. (2002) confirmed the validity of these morphologically barely distinguishable species, and suggested that these muscle-infecting species grouped according to fish-host species.

Gill-parasitic Myxobolus species are a taxonomically peculiar group within myxosporeans. In most of the cases, several parasite species infect 1 fish host, colonising different gill tissues. Several authors have reported site-selection for different species (Cone \& Wiles 1985, Molnár \& Székely 1999), but the strictly defined locations of cyprinid-infecting myxosporeans in the gill apparatus were first described by Molnár 
(2002). Myxobolus species parasitising the gills were also differentiated using a combined polymerase chain reaction-restriction fragment length polymorphism (PCR-RFLP) method by Xiao \& Desser (2000) and Eszterbauer et al. (2001). Using this method, Eszterbauer (2002) confirmed that the morphologically indistinguishable $M$. elegans from orfe and $M$. hungaricus from common bream are indeed valid species. Furthermore, Eszterbauer et al. (2002) proved that $M$. pavlovskii is also present in bighead and silver carp.

The present paper reports the results of phylogenetic analyses of 10 Myxobolus species infecting the gills of cyprinids in order to determine their genetic relationship and examine the importance of tissuespecificity in the fish hosts.

\section{MATERIALS AND METHODS}

Collection of spores. Myxospores of 10 Myxobolus species were collected from 7 fish species in Hungarian natural lakes or rivers and fish farms between 1999 and 2002 (Table 1). After collection and transportation to the laboratory, the 2 to $4 \mathrm{yr}$ old fish were sacrificed using an overdose of the anaesthetic MS 222, followed by severance of the spinal cord.
For studying the occurrence of plasmodia in the gills, samples were examined with a stereomicroscope at $10 \times$ magnification. Spores isolated from the plasmodia were carefully examined under coverslip at $100 \times$ magnification with a compound microscope to identify the parasites. Digital pictures of the spore samples were also taken.

In most cases, we freed the plasmodia from the host cells or from the capsule formed by the connective tissue of the host under a stereomicroscope, and froze them at $-20^{\circ} \mathrm{C}$ in $1.5 \mathrm{ml}$ centrifuge tubes until further use. The samples contained different numbers of spores $\left(10^{2}\right.$ to $\left.10^{6}\right)$. At least 2 different samples of myxospores collected from different fish specimens at different times were used for molecular biological examinations. In the case of Myxobolus bramae, 4 samples of spores were collected from different fish specimens at different times.

DNA extraction. After defrosting the spores, samples were centrifuged at low speed $(1000 \times g)$. The spores were suspended in $500 \mu \mathrm{l}$ lysis buffer $(100 \mathrm{mM}$ $\mathrm{NaCl}, 10 \mathrm{mM}$ Tris, $10 \mathrm{mM}$ EDTA, $0.2 \%$ sodiums dodecyl sulphate [SDS], and $0.4 \mathrm{mg} \mathrm{ml}^{-1}$ Proteinase-K) and incubated at $55^{\circ} \mathrm{C}$ for 3 to $4 \mathrm{~h}$. An equal volume of Miniprep Express Matrix (BIO 101) was then added. After centrifugation at $17900 \times g$ for $1 \mathrm{~min}$, the pellet was washed once with $80 \%$ ethanol, air-dried and

Table 1. Myxobolus sp. Gill-infecting myxosporeans examined. Samples collected from sites in Hungary between 1999 and 2002

\begin{tabular}{|c|c|c|c|c|c|}
\hline Species & Fish host & Locality & $\begin{array}{l}\text { Site preference } \\
\text { in fish }\end{array}$ & $\begin{array}{l}\text { GenBank } \\
\text { No. }\end{array}$ & $\begin{array}{l}\text { Sequence } \\
\text { length (bp) }\end{array}$ \\
\hline $\begin{array}{l}\text { M. bramae } \\
\text { Reuss, } 1906\end{array}$ & $\begin{array}{l}\text { Common bream } \\
\text { Abramis brama }\end{array}$ & Lake Balaton & $\begin{array}{l}\text { Intralamellar/ } \\
\text { vascular }\end{array}$ & AF507968 & 1580 \\
\hline $\begin{array}{l}\text { M. macrocapsularis } \\
\text { Reuss, } 1906\end{array}$ & Common bream & Lake Balaton & $\begin{array}{l}\text { Intralamellar/ } \\
\text { vascular }\end{array}$ & AF507969 & 1577 \\
\hline $\begin{array}{l}\text { M. impressus } \\
\text { Miroshnichenko, } 1980\end{array}$ & Common bream & Lake Balaton & $\begin{array}{l}\text { Interlamellar/ } \\
\text { epithelial }\end{array}$ & AF507970 & 1577 \\
\hline $\begin{array}{l}\text { M. basilamellaris } \\
\text { Lom et Molnár, } 1983\end{array}$ & $\begin{array}{l}\text { Common carp } \\
\text { Cyprinus carpio }\end{array}$ & Fish farm & $\begin{array}{l}\text { Basifilamental/ } \\
\text { epithelial (?) }\end{array}$ & AF507971 & 1592 \\
\hline $\begin{array}{l}\text { M. dispar } \\
\text { Thélohan, } 1895\end{array}$ & Common carp & Lake Balaton & $\begin{array}{l}\text { Intralamellar/ } \\
\text { vascular }\end{array}$ & AF507972 & 1578 \\
\hline $\begin{array}{l}\text { M. pavlovskii } \\
\text { Akhmerov, } 1954\end{array}$ & $\begin{array}{l}\text { Bighead } \\
\text { Aristichthys nobilis }\end{array}$ & Fish farm & $\begin{array}{l}\text { Interlamellar/ } \\
\text { epithelial }\end{array}$ & AF507973 & 1578 \\
\hline $\begin{array}{l}\text { M. pavlovskii } \\
\text { Akhmerov, } 1954\end{array}$ & $\begin{array}{l}\text { Silver carp } \\
\text { Hypophthalmichthys molitrix }\end{array}$ & Fish farm & $\begin{array}{l}\text { Interlamellar/ } \\
\text { epithelial }\end{array}$ & $\begin{array}{l}100 \% \text { identical } \\
\text { with AF507973 }\end{array}$ & 1578 \\
\hline $\begin{array}{l}\text { Myxobolus sp. } \\
\text { (hungaricus-like spores) }\end{array}$ & Common bream & Lake Balaton & $\begin{array}{l}\text { Intralamellar/ } \\
\text { vascular }\end{array}$ & AY325283 & 1614 \\
\hline $\begin{array}{l}\text { M. muelleri } \\
\text { Bütschli, } 1882\end{array}$ & $\begin{array}{l}\text { Chub } \\
\text { Leuciscus cephalus }\end{array}$ & River Danube & $\begin{array}{l}\text { Intralamellar/ } \\
\text { vascular }\end{array}$ & AY325284 & 1616 \\
\hline $\begin{array}{l}\text { M. intimus } \\
\text { Zaika, } 1965\end{array}$ & $\begin{array}{l}\text { Roach } \\
\text { Rutilus rutilus }\end{array}$ & Lake Balaton & $\begin{array}{l}\text { Intralamellar/ } \\
\text { vascular }\end{array}$ & AY325285 & 1589 \\
\hline $\begin{array}{l}\text { M. obesus } \\
\text { Gurley, } 1893\end{array}$ & $\begin{array}{l}\text { Bleak } \\
\text { Alburnus alburnus }\end{array}$ & River Danube & $\begin{array}{l}\text { Intralamellar/ } \\
\text { vascular }\end{array}$ & AY325286 & 1596 \\
\hline
\end{tabular}


eluted with MilliQ-purified water, followed by centrifugation at $17900 \times g$ for $2 \mathrm{~min}$; the upper phase was then transferred into a fresh tube. DNA content was estimated by agarose gel electrophoresis against a known amount of DNA.

PCR amplification. DNA was first amplified with the $18 \mathrm{e}-18 \mathrm{~g}$ ' universal primer-pair as described by Hillis \& Dixon (1991) and modified by Andree et al. (1999), producing a $1900 \mathrm{bp}$ fragment of the 18S rRNA gene. This was followed by a second PCR amplification using the MX5-MX3 primer-pair specific for the family Myxobolidae (Andree et al. 1999). This primer-pair amplified an approximately $1600 \mathrm{bp}$ fragment from the previously amplified PCR product.

For both steps of the nested PCR, the total volume of the PCR reaction was $50 \mu \mathrm{l}$, and comprised approx. 10 to 50 ng extracted DNA in first PCR, $1 \times$ REDTaq PCR reaction buffer (Sigma), $0.2 \mathrm{mmol}$ dNTP (Sigma), 40 pmol of each primer, 2.5 U REDTaq DNA polymerase (Sigma) in Milli-Q-purified water. I used 0.1 to $1 \mu \mathrm{l}$ of the first PCR product in the nested PCR. A Perkin-Elmer GeneAmp PCR system 2400 and an MJ Research PTC-200 thermocycles were used for amplification. Amplification conditions in the first round were: $95^{\circ} \mathrm{C}$ for $50 \mathrm{~s}, 56^{\circ} \mathrm{C}$ for $50 \mathrm{~s}$ and $72^{\circ} \mathrm{C}$ for $80 \mathrm{~s}$ for 35 cycles, with a terminal extension at $72^{\circ} \mathrm{C}$ for $7 \mathrm{~min}$, followed in the second round with $95^{\circ} \mathrm{C}$ for $30 \mathrm{~s}, 46^{\circ} \mathrm{C}$ for $30 \mathrm{~s}$ and $72^{\circ} \mathrm{C}$ for $60 \mathrm{~s}$ for 35 cycles, terminating with an extension at $72^{\circ} \mathrm{C}$ for $7 \mathrm{~min}$. The PCR products were electrophoresed in $1.0 \%$ agarose gels.

Sequencing. For DNA sequencing, 8 primers were used: the MX5 and MX3 described above, and MC5, MC3, MB5, MB3, MB3f and MB5r primers, designed for sequencing in our laboratory, based on the $18 \mathrm{~S}$ rDNA sequences of Myxobolus species available in GenBank (Molnár et al. 2002). The sequences of the oligonucleotides were: MC5 (forward) 5'-CCTGAGAAACGGCTACCACATCCA-3'; MC3 (reverse) 5'-GATTAGCCTGACAGATCACTCCACGA-3'; MB5 (forward) 5'-GGTGATGATTAACAGGAGCGGT-3'; MB3 (reverse) 5'-CCAACCGCTCCTGTTAATCATC3'; MB3f (forward) 5'-GATGATTAACAGGAGCGGTTGG-3'; MB5r (reverse) 5'-ACCGCTCCTGTTAATCATCACC-3'.

The PCR products were sequenced using the PRISM ready reaction dye deoxy cycle sequencing protocol (Perkin-Elmer) with an ABI 373A automated DNA sequencer (Applied Biosystems). The nucleotide sequences were read using the Applied Biosystems 373A DNA sequencer data analysis programme. For sequence assembly, Lasergene (DNASTAR) and STADEN sequence analysis package, Version 2001.0 (Staden 1996) were used.

Phylogenetic analysis. Myxobolus sp. 18S rRNA gene sequences from GenBank were subjected to phyloge- netic analysis; they consist of $M$. cerebralis (U96492), $M$. pseudodispar from roach Rutilus rutilus (AF380145), $M$. pseudodispar from rudd Scardinius erythrophthalmus (AF380142), M. pseudodispar from white bream Blicca bjoerkna (AF380143), M. pseudodispar from common bream Abramis brama (AF380144), M. cyprini (AF380140), M. musculi (AF380141), M. pendula (AF378340), M. pellicides (AF378339), M. algonquinensis (AF378335), M. bibullatus (AF378336), M. bramae (AF085177), M. ellipsoides (AF085178), M. xiaoi 1 (AF186843), M. xiaoi 2 (AF186842), M. elegans (AF448445), M. hungaricus (AF448444) and M. lentisuturalis (AY119688) as outgroup.

Nucleotide sequences were aligned with the MultAlin computer program (Corpet 1988). Highly variable regions containing more than 5 gaps were removed from the sequences, as described by Harrach \& Benkö (1998); therefore, 1593 nucleotides were used in the phylogenetic calculations.

Phylogenetic calculations were performed with PHYLIP Version 3.573c (Felsenstein 1989). The data were analysed with parsimony (DNAPARS) and distance matrix analyses (DNADIST, using Kimura-2 distance parameter followed by FITCH with global rearrangements). Gaps of up to 5 bases were treated as special (as opposed to missing) characters. For bootstrap analysis, the mentioned programmes were preceded by SEQBOOT (molecular sequences; 1000 data sets), followed by CONSENSE.

\section{RESULTS}

\section{PCR and sequencing}

The universal 18e-18g' primers and specific primer pair MX5-MX3 successfully amplified approx. 1900 and $1600 \mathrm{bp}$ fragments of the 18S rRNA gene from every sample of Myxobolus species examined, respectively. The DNA sequences of the PCR products have been deposited in GenBank, and the Accession numbers are listed in Table 1. In each case, the sequences of the replicates were $100 \%$ identical with a previously sequenced sample of the relevant parasite species.

\section{Phylogenetic analysis}

The edited alignment was 1593 bp long. Distance matrix analysis (Fig. 1) distinguished 4 main groups with high bootstrap confidence levels. Myxobolus lentisuturalis was expected to differ most from the other species on the basis of the results of Dykova et al. (2002), and was therefore chosen as the outgroup. For 
M. xiaoi, 2 sequences did not cluster with any of the main groups. $M$. cerebralis, the only Myxobolus species infecting the head-cartilage, grouped with $M$. bramae (AF 085177) and M. ellipsoides.

Muscle-infecting parasites, including Myxobolus cyprini, M. musculi and $M$. pseudodispar collected from 4 cyprinid species, formed a separate group, as described by Molnár et al. (2002).

Other Myxobolus species located on the gills clustered in 2 separate groups. Group 1: $M$. hungaricus, $M$. intimus, $M$. obesus, a Myxobolus species unidentifiable on the basis of morphological characters, and $M$. pendula and $M$. pellicides from the gill arches of cyprinids; Group 2: M. bramae, M. macrocapsularis, M. impressus, $M$. basilamellaris, $M$. dispar, $M$. pavlovskii, M. muelleri, $M$. algonquinensis, M. elegans and $M$. bibullatus, a gill parasite from Catostomus commersoni.

Parsimony analysis confirmed this clustering pattern, but with some differences in the bootstrap values (Fig. 1). Muscle parasites segregated as described previously by Molnár et al. (2002).

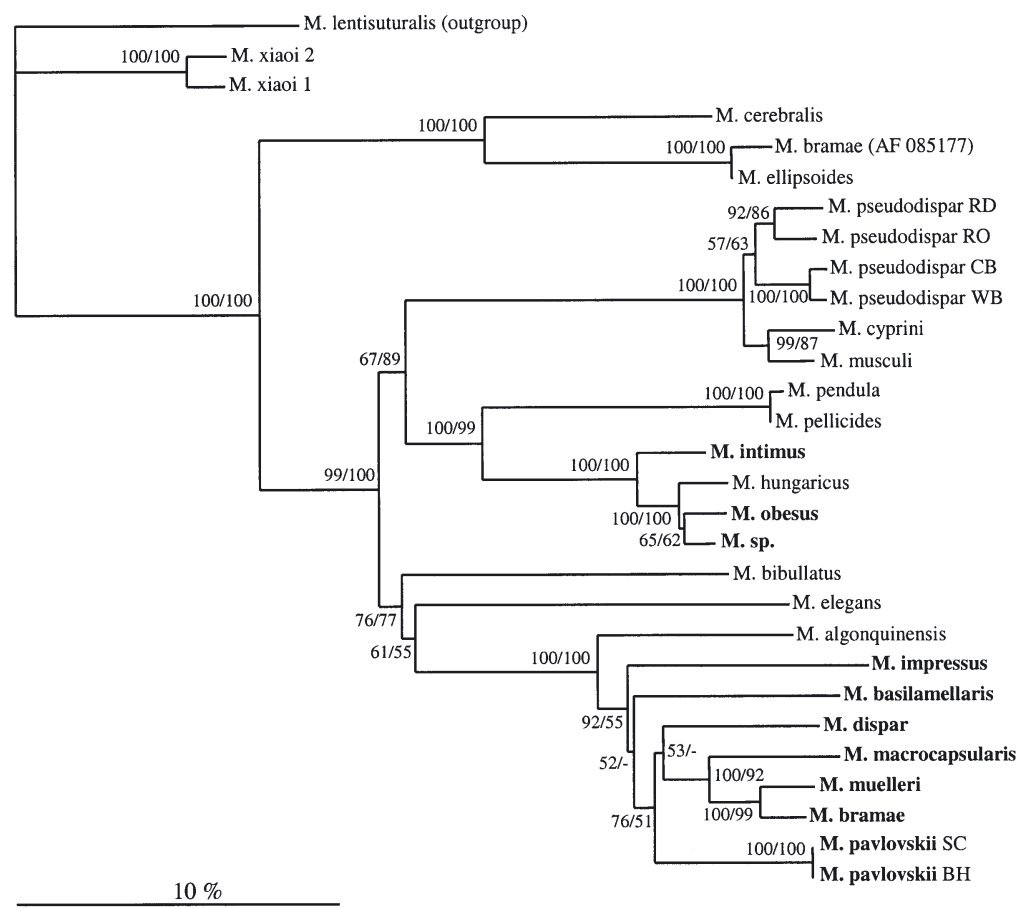

Fig. 1. Myxobolus spp. Phylogenetic tree generated by distance matrix analysis, showing relationship among myxosporeans collected from gills and muscle of cyprinids. Numbers above nodes indicate bootstrap confidence levels in percent (based on 1000 repetitions) for distance matrix/parsimony analyses, respectively. RD: rudd Scardinius erythrophthalmus, RO: roach Rutilus rutilus, CB: common bream Abramis brama, WB: white bream Blicca bjoerkna, SC: silver carp Hypophthalmichthys molitrix, BH: bighead Aristichthys nobilis

\section{DISCUSSION}

Traditionally spore morphology has been used as a basic feature for the identification of myxosporean species. In the early 1990s, other phenotypic features such as host-, organ- and tissue-specificity were suggested as important characters for specific assignment (Molnár 1994). Since then, several studies have confirmed the importance of these features and, in several cases, found them to correlate with the results of molecular data based on the comparison of $18 \mathrm{~S}$ rDNA sequences (Kent et al. 2001).

Muscle-infecting species used for phylogenetic analysis provide a good example of the difficulty of morphology-based identification. As Molnár et al. (2002) demonstrated, in the case of species infecting the skeletal muscle of cyprinids, molecular biological methods are essential for proving the validity of the species described on the basis of morphological features. In addition, Molnár et al. (2002) reported that Myxobolus pseudodispar samples collected from different fish-host species seemed to reflect the phylogenetic relationships of the fish hosts. This could be helpful in understanding the mechanism of specific divergence among myxosporeans. Using 1600 bp, aligned DNA sequences of muscle-infecting species, the results of the distance matrix and parsimony analyses in the present study gave the same clustering as described earlier by Molnár et al. (2002), using aligned DNA sequences of only $970 \mathrm{bp}$.

In the case of gill-infecting parasites, little is known about the exact location of the myxospores in fish. Many Myxobolus species develop mature spores in the gills, but in their species descriptions, investigators rarely mention the gill tissue, where the parasites form plasmodia containing mature myxospores. Indicating that, in addition to spore morphology, exact location and tissue tropism is also essential for species identification, Molnár (2002) distinguished 6 types of site preference among gill-infecting myxosporeans: (1) Species belonging to the interlamellar-epithelial type develop in the epithelium between the gill lamellae (secondary lamellae); this type of infection is represented by $M$. impressus and M. pavlovskii. (2) Parasites of the interfilamental-epithelial type usually form large plasmodia in the epithelium of filaments. (3) The basifilamental type, representing a special case of interfila- 
mental location, is represented by M. basilamellaris, which forms plasmodia on the base of the gill filaments (primary lamellae) and may also be associated with the compact connective tissue of the gill arch. (4) In the case of the intralamellar-vascular type, plasmodia develop in the vascular network of the gill lamellae, and plasmodia of different size are recognisable within a single lamella (e.g. Henneguya creplini, M. bramae and M. hungaricus). (5) Intrafilamental-vascular parasites appear in the afferent artery of the gill filaments, forming a large plasmodium at the end of filaments (e.g. M. bramae, M. macrocapsularis, M. dispar). (6) The last type has an intrafilamental-chondroidal location, with plasmodia developing in the chondroid tissue of the gill arch; a typical example is $M$. intrachondrealis from carp.

The present study examined the phylogenetic relations of 10 gill-infecting Myxobolus species. The phylogenetic trees generated by distance matrix and parsimony analyses revealed 4 main groups, which were easily distinguishable. $M$. lentisuturalis was chosen as an outgroup: although it forms plasmodia in the skeletal muscle tissue, it is located at some distance from the cluster of muscle-infecting species. Its position corresponded to that indicated by the molecular phylogenetic results of Dykova et al. (2002), who clearly demonstrated the independent position of this species among the Myxobolus species available in GenBank (including the muscle-infecting species used for phylogenetic analysis in the present study). M. xiaoi from the cartilage of the gill arch of Notemiconus crysoleucas and Notropis cornutus were located closest to $M$. lentisuturalis on the present phylogenetic tree, as also reported by Dykova et al. (2002).

Gill-infecting Myxobolus species formed 2 main groups on the phylogenetic tree. The smaller cluster contained M. obesus, M. intimus, Myxobolus sp. examined in this study and $M$. hungaricus. These species displayed high similarity in spore morphology, i.e. ovalshaped myxospores with pointed apexes, and 2 unique ribs on the surface of the spore valves, running parallel to the suture; furthermore they all belonged to the intralamellar-vascular type of gill-infecting myxosporeans. M. pendula (AF 378340) and M. pellicides (AF 378339), located in the gill arches, also clustered with these 4 species. Unfortunately, no information is available in the species descriptions in the literature concerning their tissue tropism, which may be either vascular or chondroidal type. The separation of this smaller group from the main gill-parasite cluster, and its relative closeness to the muscle-infecting group suggest that this group has a different evolutionary origin from the other gill parasites. It is possible that they developed parallel to the muscle parasites but, at some point, adapted to gill infection.
The gill parasites belonging to the main group showed similar spore morphology. Their elliptical spore shape and the polar capsules located at the apex diverged markedly from the spore shape of all other species examined. The only exception was the spores of Myxobolus elegans, which had an oval shape similar to that of $M$. hungaricus myxospores (Eszterbauer 2002). M. impressus and M. pavlovskii, which both formed plasmodia in the epithelial tissue, and M. basilamellaris (presumably originating from the gill epithelium) were clearly distinguishable from species belonging to the intralamellar-vascular type of gill myxosporeans ( $M$. bramae, $M$. macrocapsularis, $M$. dispar, and $M$. muelleri). M. algonquinensis (AF378335) from the ovary of Notropis cornutus clustered close to the species developing interlamellarly. This phylogenetic position suggests that this species forms plasmodia in epithelial-like tissue or is associated with connective tissue within the ovary.

Myxobolus cerebralis, the parasite infecting the head cartilage of salmonids, clustered with the gillparasitic $M$. bramae (AF085177) collected from Abramis brama and M. ellipsoides from Rutilus rutilus. The positions of these 2 gill parasites are rather interesting, because they differed in host-, organ- and tissue-specificity from $M$. cerebralis, although the tissue tropism of $M$. ellipsoides is not mentioned in either the GenBank or in the related article by Andree et al. (1999). It is noteworthy that the genetic difference between the sequences of $M$. bramae (AF085177) and M. ellipsoides was almost as low as (e.g.) that between M. pseudodispar samples from Abramis brama and those from Blicca bjoerkna, for which morphological differences were not recognisable (the genetic distances obtained from the distance matrix outfile were 0.0133 between $M$. bramae AF085177 and $M$. ellipsoides and 0.0107 for M. pseudodispar from A. brama and B. bjoerkna).

With regard to the Myxobolus bramae species originating from common bream, Andree et al. (1999) deposited a partial 18S rDNA sequence in GenBank under the name $M$. bramae (AF085177); however the DNA sequence of $M$. bramae (AF507968) examined in this study differed from the AF085177 sequence, although both myxospores were collected from the gills of common bream originating from Lake Balaton in Hungary. The genetic distances in the distance matrix outfile were rather high (0.3232), showing that these 2 sequences are unlikely to belong to the same parasite species. It is well known that a dozen or so myxosporean species can occur on the gills of common bream, and 8 Myxobolus species have already been described from this host fish (Landsberg \& Lom 1991). Molnár \& Székely (1999) reported 4 Myxobolus species collected from different locations in the gills of com- 
mon bream in Hungary, and suggested that the simultaneous presence of several species on the same fish specimen could cause difficulties during collection of myxospores and possible contamination. Contamination with other gill-infecting myxosporean species may be a reason for the differences found between the 2 DNA sequences assigned to $M$. bramae. To avoid contamination, it is important to collect samples very carefully and to check all ruptured cysts with a compound microscope. If the amplified PCR product can be sequenced without significant background and the sequences overlapping in 2 directions clearly merge into 1 unambiguous sequence, then the possibility of contamination or chimeric sequences is fairly low.

Since most of the samples used in this study were collected from Lake Balaton or the River Danube in Hungary, the eventual influence of geographic origin on phylogenetic relations could not be unequivocally confirmed or excluded. Nevertheless, several species originating from Ontario, Canada (Myxobolus pendula, M. pellicides, M. bibullatus and M. algonquinensis) clustered with the Hungarian species. Further species from different locations should be studied to assess if geographical location has an effect on the phylogeny of Myxobolus species as in the case of (e.g.) Kudoa species (Kent et al. 2001).

The phylogenetic tree revealed by this study demonstrated that tissue tropism may play an important role in the genetic relationships among myxosporean species. Although examination of further myxosporean species is necessary to confirm these results, they do seem to indicate that genetic separation based on tissue tropism is a more ancient evolutionary feature than (e.g.) host-specificity. The phylogenetic relationships among the Myxobolus species examined also suggest that new species evolved when parasite species came into contact with 'new' fish hosts and adapted in order to be able to infect them. After adaptation, they developed as separate species, but in most cases their location within the new fish hosts (organ and/or tissue tropism) remained unchanged.

Acknowledgements. This work was supported by the National Research Fund of Hungary (OTKA, Project No. T042464). Special thanks are due to Dr. K. Molnár and Dr. C. Székely for their essential help in collection and morphological identification of myxospores, and to Dr. B. Harrach for his useful advice during the interpretation of results.

\section{LITERATURE CITED}

Andree KB, Székely C, Molnár K, Gresoviac SJ, Hedrick RP (1999) Relationships among members of the genus Myxobolus (Myxozoa: Bivalvidae) based on small subunit ribosomal DNA sequences. J Parasitol 85:68-74

Cone DK, Wiles M (1985) Trophozoite morphology and developmental site of two species of Myxobolus (Myxozoa) parasitizing Catostomus commersoni and Notemigonus crysoleucans in Atlantic Canada. Can J Zool 63: 2919-2923

Corpet F (1988) Multiple sequence alignment with hierarchical clustering. Nucleid Acids Res 16:10881-10890

Dykova I, Fiala I, Nie P (2002) Myxobolus lentisuturalis sp. n. (Myxozoa: Myxobolidae), a new muscle-infecting species from Prussian carp, Carassius gibelio from China. Folia Parasitol 49:253-258

Eszterbauer E (2002) Molecular biology can differentiate morphologically indistinguishable myxosporean species: Myxobolus elegans and M. hungaricus. Acta Vet Hung 50: $59-62$

Eszterbauer E, Benkö M, Dán Á, Molnár K (2001) Identification of fish parasitic Myxobolus (Myxosporea) species using a combined PCR-RFLP method. Dis Aquat Org 44:35-39

Eszterbauer E, Benkö M, Molnár K (2002) Differentiation of morphologically very similar gill parasite Myxobolus species (Myxosporea) by restriction fragment length polymorphism (PCR-RFLP) method. Magy Állatorv Lapja 124: 361-366 (in Hungarian)

Felsenstein J (1989) PHYLIP-Phylogeny Inference Package, Version 3.2. Cladistics 5:164-166

Harrach B, Benkö M (1998) Phylogenetic analysis of adenovirus sequences. In: Wold WSM (eds) Methods in molecular medicine, Vol 21. Adenovirus methods and protocols. Humana Press, Totowa, NJ, p 309-339

Hervio DML, Kent ML, Khattra J, Sakanari J, Yokoyama H, Devlin RH (1997) Taxonomy of Kudoa species (Myxosporea) using small subunit ribosomal DNA sequence. Can J Zool 75:2112-2119

Hillis DM, Dixon T (1991) Ribosomal DNA: molecular evolution and phylogenetic inference. Q Rev Biol 66:411-453

Kent ML, Khattra J, Hedrick RP, Devlin RH (2000) Tetracapsula renicola $\mathrm{n}$. sp. (Myxozoa: Saccosporidae); the PKX myxozoan-the cause of proliferative kidney disease of salmonid fishes. J Parasitol 86:103-111

Kent ML, Andree KB, Bartholomew JL, El-Matbouli M and 12 others (2001) Recent advances in our knowledge of the Myxozoa. J Eukaryot Microbiol 48:395-413

Landsberg JH, Lom J (1991) Taxonomy of the genera of the Myxobolus/Myxosoma group (Myxobolidae: Myxosporea), current listing of species and revision of synonyms. Syst Parasitol 18:165-186

Molnár K (1994) Comments on the host, organ and tissuespecificity of fish myxosporeans and on the types of their intrapiscine development. Parasitol Hung 27:5-20

Molnár K (2002) Site preference of fish myxosporeans in the gill. Dis Aquat Org 48:197-207

Molnár K, Székely C (1999) Myxobolus infection of the gills of common bream (Abramis brama L.) in Lake Balaton and in the Kis-Balaton reservoir, Hungary. Acta Vet Hung 47: 419-432

Molnár K, Eszterbauer E, Székely C, Dán Á, Harrach B (2002) Morphological and molecular biological studies on intramuscular Myxobolus spp. of cyprinid fish. J Fish Dis 25: 643-652

Salim KY, Desser SS (2000) Descriptions and phylogenetic systematics of Myxobolus spp. from cyprinids in Algonquin Park, Ontario. J Eukaryot Microbiol 47:309-318

Shulman SS (1966) Myxosporidii fauny SSR. Izdatel'stvo Nauka, Moscow

Staden R (1996) The staden sequence analysis package. Mol Biotechnol 5:233-241

Xiao C, Desser SS (2000) Molecular characterization of myxozoan parasites from Lake Sasajewun, Algonquin Park, Ontario, by riboprinting. J Eukaryot Microbiol 47:85-89 